\title{
Tax Accounting System for Geotechnical Construction
}

\author{
Anatolii Kholkin ${ }^{1, *}$, Alevtina Zonova ${ }^{1}$, Alexander Bespyatyh, Nadezhda Gamulinskaya ${ }^{1}$, \\ and Olga Artemyeva ${ }^{1}$ \\ ${ }^{1}$ Vyatka State University, Moskovskaya str., 36, Kirov, 610000, Russia
}

\begin{abstract}
The importance of this research is based on the need of the tax accounting organization as information system, because that can meet the information needs of users in information useful for tax management. This need is strongly manifested in respect of geotechnical construction enterprises, because without reliable information it is impossible to make quality decisions in the tax management of these enterprises. And the right decisions in tax management ensure the survival of these enterprises in the long term. As the information system, tax accounting organization and maintenance require the description of tax accounting in terms of system approach. The purpose of this article is to give determination of tax accounting based on the implementation of a system approach, because applying a system approach will allow organizing the tax accounting, as well as functioning information system. As a result of the research, the definition of tax accounting was given from the point of view of system approach, subsystems of tax accounting were defined, and its elements were described. Also, relations between the elements were determined. Functions implemented by a tax accounting system were described, and relations between the functions were identified. This research is practically important and can be applied only in those countries where tax legislation provides for differences in an order of calculation of tax report figures and calculation of financial report figures, or where the national tax legislation permits the employment of different methods of calculation for tax and financial reports.
\end{abstract}

\section{Introduction}

In the present, because the problem of the lack of information performed in accounting system for tax management exists, the need for organization and implementation of tax accounting arises. Therefore, tax accounting as the process of collection, processing and grouping of information became one of the management system's elements as a whole. Therefore, to make the integration of tax accounting in management system correct, it is necessary to imagine and describe it as the system, and also elements and relations between them are identified. This is necessary for the proper organization and regulation of actions of the accounting staff, which engaged in tax accounting.

\footnotetext{
* Corresponding author: khav76@mail.ru
} 
For this reason, the correct tax accounting description with the use of the system approach is most important. This is especially true for countries with unstable tax regulation, where the obligation of keeping tax accounting appeared not so long ago, consequently, the experience of organization implementation of tax accounting doesn't exist. This problem is especially important for geotechnical construction enterprises due to the specifics of accounting, due to the long production cycle and the presence of specific costs. This problem is aggravated by the lack of clearly developed recommendations on the organization of tax accounting in the Russian Federation.

Tax accounting theory and practice are disclosed in books and papers of the following authors: Anuschka Bakker, Tjeerd van den Berg, Bart Janssen [1], Barry J. Epstein, Ralph Nach, Steven M. Bragg [2], Benedikt Zinn [3], Christopher H. Hanna [4], Donald E. Kieso, Jerry J. Weygandt, Terry D. Warfield [5], Frank L. Brunetti [6], F. Michael Cochrane [7], Glenn R. Carrington [8], Henry Lunt [9], Joanne M. Flood [10], Lin Gang [11], Lynne Oats, Bill Telford [12], Matthias Walz, Jens Briese, Martin Haas, Gerd Gutekunst [13], Michael B. Lang, Elliott Manning, Mona L. Hymel [14], Michel Glautier, Brian Underdown, Deigan Morris [15], Misrak Tesfaye Abate [16], Peter H. J. Essers [17], Richard Petersen [18], Robert N. Antony, James S. Reece [19], Rod Caldwell [20], Roger H. Hermanson, James Don Edwards, Roland Frank Salmonson [21], Stephen F. Gertzman [22], Tami Van Tassell, David Beaver, Bill Maloney [23], Trent Green [24], Zhang Zhi Feng, Li Hui Si Zhu [25]

Unfortunately, most authors have just focused on the recording technique development, that is, the regulation of accounting process, without description of tax accounting as a system.

However, the applicable method of this problem solving does not allow using it with due efficiency and applying it in the environment of dynamically varying fiscal legislation, as exemplified by the laws of the Russian Federation. The problem of this method application lies in imperfection of methods not based on system approach implementation.

The result of this problem is an impossibility to create an efficient tax accounting system focused on maximal satisfaction of users' information needs with minimal expenses for records keeping. Besides, this causes an impossibility of an optimal control over tax payments. This problem is worsened by the high instability of the tax legislation of the Russian Federation.

The hypothesis of this research is that tax accounting, as an object of organizational activities and management, is an open complicated dynamic system. This system shall consist of certain interconnected elements.

Thus, the purpose of this research is the development of description of tax accounting on the base of system approach principles, identifying elements and relation between them, and functions performed by tax accounting as a system.

\section{Methods and materials}

The following methods were applied in this research: analysis, synthesis, deduction, induction, system analysis methods, system building methods, and methods of making decisions.

Tax legislation rules, applicable laws regulating accounting, and articles and books of national and foreign authors listed in the previous section were used as the basis of the research.

The research was carried out by successive solving of the following tasks, providing for the set goal achievement:

- To develop the definition of tax accounting based on the system approach,

- To determine the structure of elements of the tax accounting system, 
- To determine the hierarchy and connections of the elements of the tax accounting system.

\section{Results}

The following results were obtained after stated above tasks were solved.

Based on the system approach implementation, tax accounting shall be defined the following way.

Tax accounting is the dynamic, self-developing, open, optimally functioning, and rationally arranged system regulated in time and space, enabling collection, grouping, consolidation, and disclosure of data required by users for timely and correct calculation and payment of taxes and duties, preparation and presentation of tax reports, and transfer of data required for tax control and making decisions for management of tax payments of the enterprise.

Tax accounting, as the object of organizational and managerial activities, consists of the following consolidated elements - tax accounting subsystems - namely:

1. The "methodology" subsystem

2. The "process" subsystem

3. The "organization" subsystem

4. The "technique" subsystem

The description for each subsystem was developed, and the hierarchy and relations between the above subsystems were determined. The description of tax accounting system functions was given, and function relationships were recognized. It was indicated, that recommendations on the tax accounting system organization must be developed via determination of all the said subsystem within a geotechnical construction enterprise.

\section{Discussions}

Tax accounting in geotechnical construction enterprise shall be organized as a dynamic system, i.e. a system able to change its status under the influence of internal and external conditions. In particular, the internal condition can be the change of internal users' informational needs, and the external condition can be tax legislation amendments.

Tax accounting shall be organized as a self-developing system, because it shall choose a direction of its development itself, focusing on maximal satisfaction of the users' informational needs with minimal costs of its operation.

Tax accounting shall be an open system, i.e. shall interact with the organizational environment proactively both obtaining the data required for its operation and providing a result of its operation - the grouped data - to the environment.

The tax accounting system shall be operated in the optimal way, i.e. uninterruptedly and continuously without lack or misrepresentation of information.

Tax accounting shall be arranged in the rational way, which is an essential condition of compliance with the requirement of rationality of accounting: the fullest satisfaction of users' informational needs with minimal costs of the system operation.

Further, the definition describes the purpose and tasks of a tax accounting system.

The purpose of tax accounting is the fullest satisfaction of the users' needs of information required for correct and timely calculation and payment of taxes and duties, preparation and presentation of tax declarations and other forms of tax reports, fiscal control preparation, and making decisions for tax payment management.

The tasks of tax accounting enabling this purpose achievement can be defined the following way: 
- Collection of data required for correct and timely calculation of taxes and duties,

- The data grouping and consolidation,

- Preparation of tax declarations and other tax reports based on the consolidated information,

- Presentation of tax declarations and other tax reports, as well as other information under occasional and regular requests of the users, including tax authorities.

The functions of tax accounting performed within an enterprise are:

1. An informational function allows obtaining valid data required for calculation of taxes and duties (fiscal information). This is a basic function.

2. Tax calculation function provides to calculate actually payable tax payments based on the fiscal information upon the end of each tax period (report period).

3. A function of preparation and presentation of tax reports allows executing and submitting timely tax declarations and other information to the specified addresses.

4. A function of tracking of applicable and possible tax benefits, as well as control over legal basis and legal and instrumental grounds of tax benefits (tax benefit documentation and control). This function is not a basic function, and it is focused on documentation of the applicable tax benefits or tax benefits decided to be applied, because making decisions on benefits application is not a function of tax accounting, but a function of tax management.

5. A function of tax payment reduction through decrease of a number of tax errors and timely tax payment transfer. A correctly arranged tax accounting system can allow obtaining valid tax information, which will decrease the number of errors in tax calculation and filling in tax declaration. While this, in its turn, will allow calculating taxes correctly, pay them timely and fully, and submit tax declarations timely. It will also decrease the risk of being held liable for tax legislation violation.

6. Presentation of data required for tax management to all interested users. This function is closely connected with report preparation and presentation, i.e. the function of support of making decisions.

7. Simplification of tax control procedures. Simplification of tax control procedures is achieved through the improvement of informational support of carrying out tax control procedures.

8. A function of informational and legal support. This is not a basic function, but its implementation is necessary for ensuring the normal and efficient operation of all the other functions. Thus, this is a support function.

Besides, all functions of tax accounting are interconnected and form a system. The function relations appear in the following. If the informational function is not performed, the tax information is missed, therefore, it is impossible to calculate the taxes (to perform the tax calculation function), to execute and submit the tax reports (to perform the function of preparation and presentation of tax reports), and submit the data required for tax collection. It is impossible to reduce tax payments through decreasing the number of errors without due performance of all the other functions of tax accounting. The function of tracking of applicable and possible tax benefits determines the list of payable taxes and duties and, thus, calculated taxes and the structure of tax information, and, consequently, influences the volume of operations within the informational function and the function of simplification of tax control procedures. However, the implementation of the function of tracking of tax benefits is impossible without information, i.e. without the informational function preparation. Besides, the tax accounting system cannot be operated efficiently without the due preparation of the function of informational and legal support. Thus, the informational function is a primary one for tax accounting, and the other ones are auxiliary or supporting.

As stated above, the tax accounting system consists of subsystems. Subsystem consists of determinate elements. 
So, the "methodology" subsystem includes the following elements: conception, purpose, tasks, functions, method and empirical experience.

The "process" subsystem includes the below elements:

- An accounting policy (as part of tax accounting organization),

- Accounting procedures,

- Informational support of the accounting.

The "organization" subsystem includes the following elements:

- A functional structure of the accounting department,

- An organizational structure of the accounting department,

- Functions of each separate accounting officer, their recording in internal regulations,

- Professional and personal competency of each accounting officer in the sphere of tax accounting and application of tax legislation and other regulations.

The "technique" subsystem includes:

- Tax accounting technology,

- A form of accounting,

- A system of document flow and tax registers,

- Reports

Unfortunately, the limited volume of the article does not allow describing all the elements of subsystems in full.

The relationship of tax accounting subsystems appears through relations between separate elements was included in the subsystem. This could be illustrated by following examples. The relation between the "methodology" subsystem with the "process" subsystem appears in the fact that the element "Accounting procedures" is nothing but an implementation of element "methods" from "methodology" subsystem. The "organization" subsystem and the "process" subsystem are interconnected by: functions of each separate accounting officer, including execution of accounting procedures. The "methodology" subsystem connects with the "technique" subsystem, because the tax accounting technology bases on the usage of methods. The "organization" subsystem and the "technique" subsystem related between each other by the fact that the tax accounting technology is regulated in relevant job responsibilities of a particular employee of tax accounting department.

\section{Conclusions}

The application of system approach to the development of tax accounting enabled us to give a definition and description of a tax accounting system through system characteristics and attributes. The tax accounting elements were also defined and relations between them were determined. The requirements to certain elements were determined. The functions performed by a tax accounting system within an enterprise were determined, and relations between them were described.

The determination of the elements of tax accounting as a system described in this article further allows developing practical advice on tax accounting organization within any enterprise acting in all spheres and industries, especially in geotechnical construction. However, the practical advice shall just contain a statutory recording of the descriptions and regulation of all the above elements of a tax accounting system.

This study is of significant practical importance and is applicable only in those countries, whose tax legislation provides for the procedure for calculating tax reporting indicators other than the procedure for calculating accounting (financial) indicators, or where national tax legislation allows for the use of different methods for calculating tax and financial reporting indicators as a method of tax planning. 
In general, the organization of tax accounting in geotechnical construction enterprise as a system containing all the above interconnected elements provides for increase of the efficiency of the reporting function in terms of satisfaction of internal and external users' needs of information required for tax payment or tax income management. Efficiency increase in such case means the increase of validity and operational efficiency of tax report data decreasing the costs of accounting.

\section{References}

1. A. Bakker, T. van den Berg, B. Janssen, Tax Accounting: Unravelling the Mystery of Income Taxes (IBFD, Amsterdam, 2015)

2. B. J. Epstein, R. Nach, S. M. Bragg, Wiley GAAP 2010: Interpretation and Application of Generally Accepted Accounting Principles (John Wiley \& Sons, New York, 2009)

3. B. Zinn, Tax Accounting in Germany (JOSEF EUL VERLAG Gmbh, Lohmar, 2012)

4. C. H. Hanna, Corporate Income Tax Accounting (Thomson Reuters Tax \& Accounting, 2013)

5. D. E. Kieso, J. J. Weygandt, T. D. Warfield, Fundamentals of Intermediate Accounting 2006 FASB Update (John Wiley \& Sons, New York, 2005)

6. F. L. Brunetti, Fundamentals of Federal Tax Accounting (American Law Institute, Philadelphia, 2008)

7. F. M. Cochrane, Tolley's Accounting Principles for Tax Purposes (LexisNexis, Dayton, 1999)

8. G. R. Carrington, Tax Accounting in Mergers and Acquisitions, 2015 Edition (CCH Incorporated, Chicago, 2014)

9. H. Lunt, Fundamentals of Financial Accounting (Elsevier, Oxford, 2009)

10. J. M. Flood, Wiley GAAP 2015: Interpretation and Application of Generally Accepted Accounting Principles 2015 ( John Wiley \& Sons, New York, 2014)

11. L. Gang, Tax accounting (Renmin University of China Press, Beijing, 2012)

12. L. Oats, B. Telford, Accounting Principles for Tax Purposes (Bloomsbury Publishing Plc, London, 2014)

13. M. Walz, J. Briese, M. Haas, G. Gutekunst, IAS 12 - Ertragsteuern: Kommentierung und Tax Accounting (John Wiley \& Sons, New York, 2013)

14. M. B. Lang, E. Manning, M. L. Hymel, Federal Tax Accounting, 2nd Edition (LexisNexis, Dayton, 2011)

15. M. Glautier, B. Underdown, D. Morris, Accounting: Theory and Practice (Financial Times Press, Indiana, 2011)

16. M. T. Abate, Ethiopian Tax Accounting: Principles and Practice (Addis Ababa, 2011)

17. P. H. J. Essers, The Influence of IAS/IFRS on the CCCTB, Tax Accounting, Disclosure and Corporate Law Accounting Concepts: 'a Clash of Cultures' (Wolters Kluwer Law \& Business, Alphen aan den Rijn, 2009)

18. R. Petersen, CCH Accounting for income tax (CCH, Chicago, 2008)

19. R. N. Antony, J. S. Reece, Accounting principles, 6th Ed. (A.I.T.B.S. Publishers \& Distributors, Delhi, 1995)

20. R. Caldwell, Tax Accounting for Small Business: A Guide to Understanding the Simplified Tax System (Wiley, New York, 2004) 
21. R. H. Hermanson, J. D. Edwards, R. F. Salmonson, Accounting principles (Business Publications, Plano, 1987)

22. S. F. Gertzman, Federal Tax Accounting (Thomson Reuters/WG \& L, 2017)

23. T. Van Tassell, D. Beaver, B. Maloney, Income Tax Accounting Under IFRS (Tax Management Inc, Arlington, 2009)

24. T. Green, The Missing Tax Accounting Guide: A Plain English Introduction to ASC 740 Tax Provisions (CreateSpace Independent Publishing Platform, 2017)

25. Z. Z. Feng, L. H. S. Zhu, Income Tax Accounting Theory and Practice (Chinese Edition) (Social Sciences Academic Press, Beijing, 2011) 